\title{
Supported Single-Site Organometallic Catalysts for the Synthesis of High-Performance Polyolefins
}

\author{
Madelyn M. Stalzer • Massimiliano Delferro • \\ Tobin J. Marks
}

Received: 3 November 2014/Accepted: 4 November 2014/Published online: 18 November 2014

(C) Springer Science+Business Media New York 2014

\begin{abstract}
Single-site organometallic catalysts supported on solid inorganic or organic substrates are making an important contribution to heterogeneous catalysis. Early and late transition metal single-site catalysts have changed the polyolefin manufacturing industry and research with their ability to produce polymers with unique properties. Moreover, several of these catalysts have been commercialized on a large scale. Their heterogenization for slurry or gas phase olefin polymerization is important to produce polyolefin as beads and to avoid reactor fouling. The large majority of supports currently used in industry are inorganic materials $\left(\mathrm{SiO}_{2}, \mathrm{Al}_{2} \mathrm{O}_{3}, \mathrm{MgCl}_{2}\right.$ ), with silica being the most important. Single-site supported catalysts are most commonly prepared by molecular-level anchoring/chemisorption, in which a molecular precursor undergoes reaction with the surface while maintaining most of the ligand sphere of the parent molecule. Chemisorption of discrete organometallic complexes on solid supports yields catalysts with well-defined active sites, greater thermal stability than the homogeneous analogues, and decreased reactor fouling versus the homogeneous analogues. This review presents a detailed account of the synthesis, characterization and polymerization properties of single-site catalysts supported on metal oxides and metal sulfated oxides, primarily carried out at Northwestern University.
\end{abstract}

Keywords Heterogeneous catalysis - Homogeneous catalysis · Polymerization

\author{
M. M. Stalzer · M. Delferro $(\bowtie) \cdot$ T. J. Marks $(\bowtie)$ \\ Department of Chemistry, Northwestern University, Evanston, \\ IL 60208-3113, USA \\ e-mail: m-delferro@northwestern.edu \\ T. J. Marks \\ e-mail: t-marks@northwestern.edu
}

\section{Introduction}

Polyolefins are the most widely used class of polymers with a global consumption of approximately 211 million metric tons with an average price on the US market of $\$ 1,422.00$ per metric ton [1]. Notwithstanding "green" concerns, polyolefins still surpass biopolymers in performance and energy efficiency [2]. While biopolymers rank high in terms of green design metrics, their production incurs relatively large environmental impact. On the other hand, polyolefins rank first in terms of life cycle assessment. Polyethylene is the simplest (and cheapest) polyolefin, having the general formula $\left(-\mathrm{CH}_{2}-\right)_{\mathrm{n}}$. It is typically a semicrystalline material, with mixture of interconnected crystalline and amorphous regions. In terms of microstructure, different polyethylenes are commercially available, with completely dissimilar chemical, physical, and mechanical properties. Polyethylene is conventionally classified as either: (i) high-density polyethylene (HDPE), (ii) low-density polyethylene (LDPE), or (iii) linear lowdensity polyethylene (LLDPE). HDPE has small amounts of branching $(<1 \%)$, with a density of $0.941 \mathrm{~g} / \mathrm{cm}^{3}, \mathrm{LDPE}$ contains a mixture of long $\left(>\mathrm{C}_{6}\right)$ and short branches (methyl, ethyl, butyl) with a density of about $0.92 \mathrm{~g} / \mathrm{cm}^{3}$, while LLDPE has a high content of short branches $\left(<\mathrm{C}_{6}\right)$ and a density less than $0.925 \mathrm{~g} / \mathrm{cm}^{3}$ (Fig. 1) [3]. The type and degree of branching underlie many of the differing HDPE, LDPE, and LLDPE physical properties because they affect crystallinity and the extent of amorphous character [4].

Historically, polyolefins were produced using highly active heterogeneous catalysts prepared from supported groups 4 or 6 halides, activated by aluminum alkyls. In the 1950s, the first olefin polymerization catalyst was reported by Phillips Petroleum constituted essentially of $\mathrm{Cr} /$ silica or 
Fig. 1 Examples of commercial polyethylenes

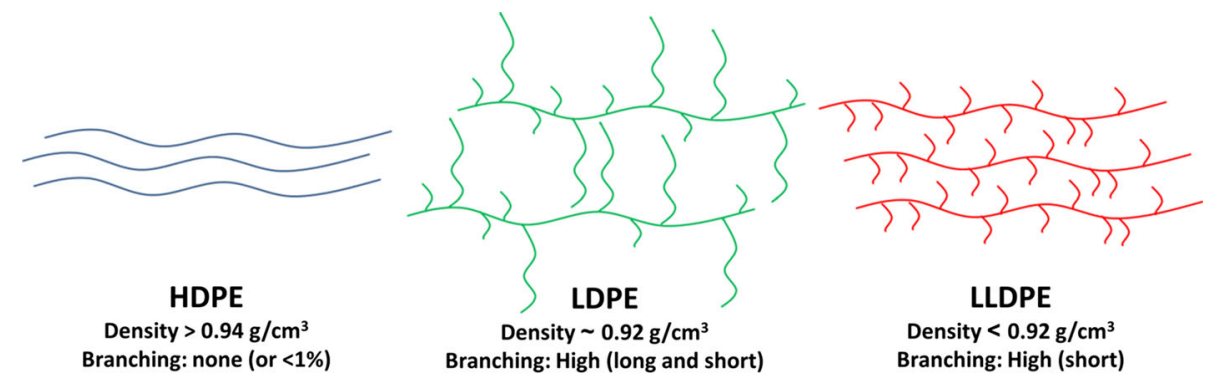

Fig. 2 Proposed structures for Phillips catalyst (left) and supported Ziegler-Natta catalyst on $\mathrm{MgCl}_{2}$ (right)

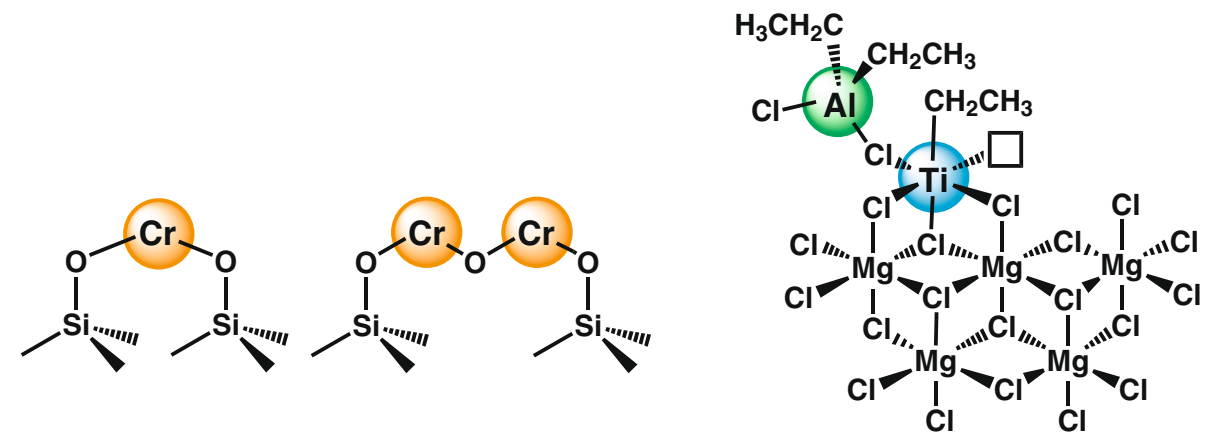

Phillips Catalyst
Ziegler-Natta Catalyst

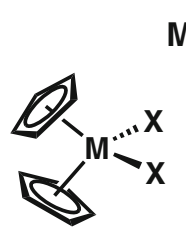

\section{Metallocene Catalysts}
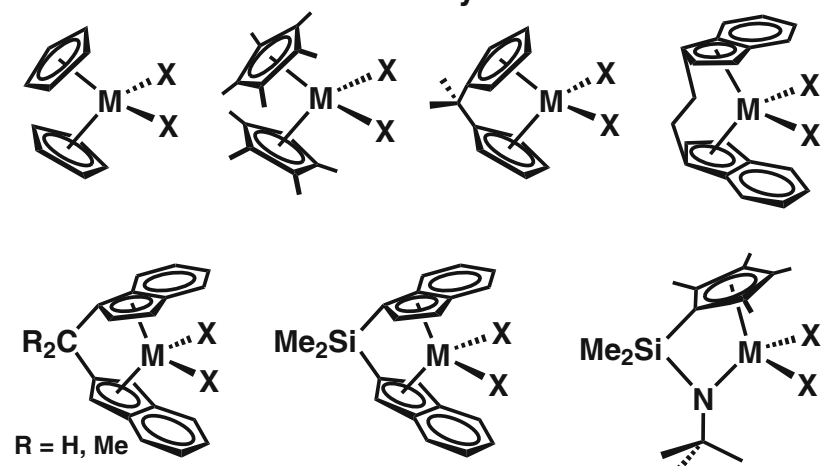

$\mathbf{M}=\mathrm{Ti}, \mathrm{Zr}$

$X=$ Halogen, Alkyl

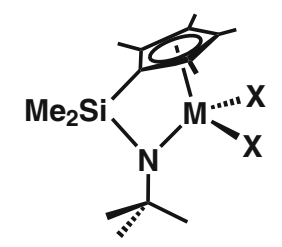

\section{Co-Catalysts/Activators}<smiles>CC1O[Al](C)O[Al](C)O[Al](C)O[Al](C)O1</smiles><smiles>Fc1c(F)c(F)c(Br)c(F)c1F</smiles>
$\mathrm{Ph}_{3} \stackrel{+}{\mathrm{C}} \overrightarrow{\mathrm{B}}$ ${ }_{3} \stackrel{+}{N} H$ B

Fig. 3 Selected examples of metallocene precatalysts and activating cocatalysts

Cr/silica-alumina (Fig. 2) [5-7]. This catalyst system, modified and optimized, is used today by various companies around the world, and accounts for a large share

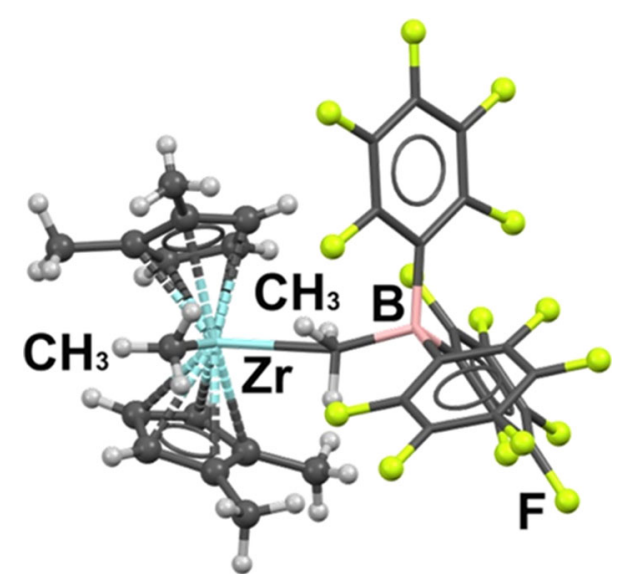

Fig. 4 Molecular structure of the mononuclear ion-pair polymerization catalyst $\left[\left(1,2-\left(\mathrm{CH}_{3}\right)_{2} \mathrm{C}_{5} \mathrm{H}_{3}\right)_{2} \mathrm{ZrCH}_{3}\right]^{+}\left[\mathrm{CH}_{3} \mathrm{~B}\left(\mathrm{C}_{6} \mathrm{~F}_{5}\right)_{3}\right]^{-}$. Adapted with permission from J Am Chem Soc (1991) 113:3623-3625 [26]. Copyright 1991 American Chemical Society

( $\sim 40$ to $50 \%$ ) of the world's HDPE production. In 1963 Karl Ziegler and Giulio Natta received the Nobel Prize in Chemistry "for their discoveries in the field of the chemistry and technology of high polymers" [8]. Heterogeneous Ziegler-Natta catalysts are binary combinations of supported $\mathrm{TiCl}_{4}$ and $\mathrm{AlR}_{3}\left(\mathrm{R}=\right.$ alkyl, aryl, hydride) on $\mathrm{MgCl}_{2}$ (Fig. 2), and are still employed on a large scale to produce isotactic polypropylene ( $i \mathrm{PP}$ ) and HDPE [9-12]. In the late 1980s, molecule-based group 4 metallocene homogeneous olefin polymerization catalysts emerged from discoveries 


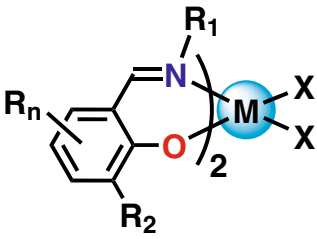

$\mathrm{M}=\mathrm{Ti}, \mathrm{Zr}, \mathrm{Hf}$

$X=$ Alkyl, Halogen

Fujita

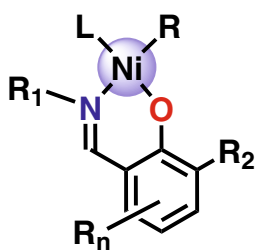

$\mathrm{R}=$ Alkyl, Ary

$\mathrm{L}=$ Phosphine, Solvent

Grubbs

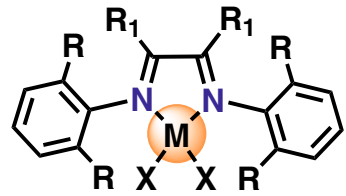

$\mathrm{M}=\mathrm{Ni}, \mathrm{Pd}$

$\mathrm{X}=$ Halogen

Brookhart

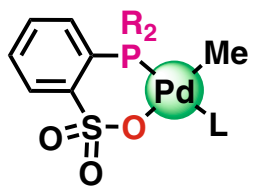

$\mathrm{R}=$ Aryl, Alkyl

$\mathrm{L}=$ Py, Ether, DMSO

Drent

Fig. 5 Examples of non-metallocene olefin polymerization catalysts

by Walter Kaminsky [13-15]. A methylaluminoxane (MAO, Fig. 3) cocatalyst, a partially hydrolyzed trimethyl aluminium reagent, was found to be an efficient activator for these homogeneous group 4 metallocene catalysts (Fig. 3) [13-15]. This highly active homogeneous system allows for tuning of the product polymer microstructure $\left(M_{\mathrm{w}}\right.$, PDI, \% comonomer incorporation, tacticity) exclusively by varying the organic ancillary ligands surrounding the group 4 metal [14, 16-24].

Another major advance in olefin polymerization catalysis was the independent discovery in the 1990s by the Marks group [25, 26] at Northwestern and Ewen and coworkers at Exxon Chemical Company [27] of catalytically active, isolable, and structurally well-defined, 1:1 catalyst/ cocatalyst ion pairs derived from metallocene dialkyls and the organo-Lewis acid $\mathrm{B}\left(\mathrm{C}_{6} \mathrm{~F}_{5}\right)_{3}$ (Fig. 4) [28-30].

Detailed thermodynamic/thermochemical and NMR molecular dynamics studies of the ion-paired catalytic systems show that $\left[\mathrm{L}_{\mathrm{n}} \mathrm{M}-\mathrm{R}\right]^{+}\left[\mathrm{MeB}\left(\mathrm{C}_{6} \mathrm{~F}_{5}\right)_{3}\right]^{-}$polymerization properties are sensitive to metal ancillary ligation, $\mathrm{R}$ substituent, borane acidity, and solvent polarity. These trends can be understood in terms of the ability of the metallocene ancillary ligands to stabilize the cationic charge, the homolytic $\mathrm{M}-\mathrm{CH}_{3}$ bond dissociation enthalpies, and the electron withdrawing power of the borane substituents. These new "single-site" catalytic systems are far better defined and more rationally tunable in terms of catalytic activity and product selectivity, structure, thermodynamics, and mechanism, which enable the discovery of new catalysts, cocatalysts, deeper mechanistic understanding of both the homogeneous and heterogeneous systems, and macromolecules with dramatically different properties, and finally, large-scale industrial processes [31].

At the beginning of the 1990s, new generations of "nonmetallocene" [32-35] catalysts based on various phenoxyiminato ligands were reported by Fujita and co-workers (Group 4, Fig. 5) [36-42] and Grubbs and co-workers (Group 10, Fig. 5) [43-46]. In 1995, Brookhart and coworkers reported high activity $\alpha$-diimine $\mathrm{Ni}$ and $\mathrm{Pd}$ complexes which are able to co-polymerize ethylene with polar monomers (Fig. 5) [47-53]. In addition, in early 2000, Drent and co-workers [54] at Shell reported that neutral Pd(II) catalysts generated in situ from phosphonium-sulfonate ligands copolymerize ethylene and methyl acrylate to produce linear copolymers (Fig. 5) [55]. Especially in the case of group 4, these new catalysts and cocatalyst/activators have achieved great success in the production of advanced polyolefin materials [4]. The new systems are able to control product molecular weight, polydispersity, comonomer enchainment level and pattern, the tacticity of poly( $\alpha$-olefins) [17, 56, 57], copolymerization of olefins with polar comonomers (group 10) [54, 55, 58-62], and the catalytic synthesis of block copolymers by processes such as chain shuttling polymerization [63-67].

Heterogeneous olefin polymerization catalysts offer many distinct attractions, such as thermal robustness, high activity, high degrees of coordinative unsaturation, high product molecular masses, and in some cases, high isoselectivity. However, understanding structure/reactivity/ selectivity relationships in these systems is severely complicated by uncertainties in the active site structure(s) and the percentage(s). For all these reasons, grafting welldefined, single-site homogeneous molecular catalysts on surfaces has emerged as a powerful tool to create new catalysts, to characterize surface species, and thus to establish unambiguous structure/activity relationships [6873]. For example, it has been shown that well-defined zirconium hydrides supported on alumina are highly active catalysts for alkane hydrogenolysis (Fig. 6a) [74] and silica-supported tungsten [75-78] and molybdenum complexes (Fig. 6b) [79-82] are effective catalysts for alkane metathesis [69, 71, 77, 83-85].

In many cases, the catalytic activities of the supported organometallics far surpass those achievable with the analogous metal complexes in homogeneous system. Also, the structural nature of the molecule-derived adsorbates can be well characterized by a combination of techniques such as solid state NMR, X-ray photoelectron spectroscopy 
A

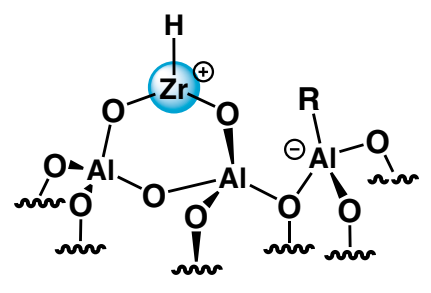

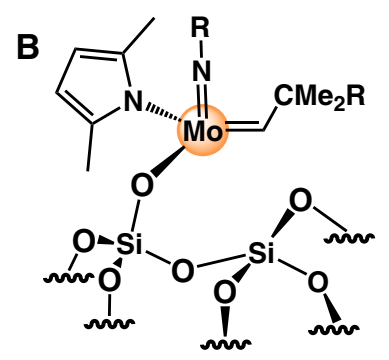

Fig. 6 Selected examples of supported organometallic catalysts

(XPS), vibrational spectroscopy (FT-IR), X-ray absorption spectroscopy (XAS), and density functional theory (DFT) calculations. However despite this progress, many important mechanistic and structural details remain unclear such as (i) the nature of both the catalytically active and catalytically inactive surface species created on chemisorption, including the degree to which the original ligation is preserved; (ii) the number and type of bonds established to the oxide support and the most reactive oxide surface sites for the grafting process; and (iii) the adsorbate structures which maximize catalytic activity. Thus, comparing the key aspects of the adsorbate-oxide surface interaction with the relevant features in well-characterized solution-phase analogues offers an opportunity to better understand the distinctive aspects of the surface organometallic chemistry.

This review focuses primarily on recent research at Northwestern in which organo-groups 4 and 5, and organoactinide complexes are supported on dehydroxylated $\gamma$-alumina [86, 87] and sulfated metal oxides [88-90]. The combined application of solid-state NMR spectroscopy, periodic DFT calculations, and metal X-ray absorption spectroscopy indicates formation of organometallic cations having a largely electrostatic $\mathrm{L}_{\mathrm{n}}-\mathrm{M}^{+}$... surface $^{-}$interaction. It will be also seen that these species are highly active catalysts for $\boldsymbol{\alpha}$-olefin polymerization and arene hydrogenation, with nearly $\sim 100 \%$ of active site in the case of sulfated metal oxide supports.

\section{Discussion}

\subsection{Dehydroxylated $\gamma$-Alumina Supports}

Dehydroxylated $\gamma$-alumina (DA) and partially dehydroxylated $\gamma$-alumina (PDA) surfaces show pronounced Lewis acidic character due to coordinatively unsaturated surface Al sites [74, 91-93] that are reminiscent of analogous MAO cocatalysts and structurally well-defined perfluoroarylborane and borate catalyst activators [28-30]. From a coordination chemistry point of view, the accessibility of both Brønsted and Lewis acid sites on alumina offers a unique complexation environment. DA and PDA substrates are prepared by heating $\gamma$-alumina (Scheme 1) with consequent elimination of water molecules and formation of Al-O-Al moieties [74, 91-93]. Reaction of organometallic precursors with PDA or DA yields highly active catalysts for both olefin and arene hydrogenation and olefin polymerization (vide infra). Heterolytic $\mathrm{M}-\mathrm{C}$ bond scission is the primary chemisorption mechanism for highly Lewis acidic surfaces [73]. Here the hydrocarbyl anion is transferred to the surface (Lewis acid sites) to give rise to a cationic organometallic adsorbate (Scheme 1, Pathway A). In marked contrast to these results, chemisorption of organometallic precursors on $\mathrm{SiO}_{2}, \mathrm{Al}_{2} \mathrm{O}_{3}$, and $\mathrm{SiO}_{2}-\mathrm{Al}_{2} \mathrm{O}_{3}$ surfaces having appreciable coverage by weakly acidic $\mathrm{OH}$ groups, predominantly yields covalently bound, poorly electrophilic species via $\mathrm{M}-\mathrm{CH}_{3}$ protonolysis with $\mathrm{CH}_{4}$ evolution (Scheme 1, Pathway B) [72]. While these sites can be characterized by high-resolution solid state NMR and X-ray adsorption fine structure spectroscopy (EXAFS), they display minimal catalytic turnover in the absence of added activators (e.g., MAO or $\left.\mathrm{B}\left(\mathrm{C}_{6} \mathrm{~F}_{5}\right)_{3}\right)$, and the fraction of catalytically significant sites is unknown [94, 95].

The ${ }^{13} \mathrm{C}$ CPMAS NMR spectrum of $\mathrm{Cp}_{2} * \mathrm{Th}\left({ }^{13} \mathrm{CH}_{3}\right)_{2}$ chemisorbed on DA [96] shows the transfer of a methide anion from the actinide center to a quadrupolar Al Lewis acid site on the surface. The $\mathrm{Al}-{ }^{13} \mathrm{CH}_{3}$ resonance appears at the characteristic upfield position $(\delta=-5 \mathrm{ppm})$, whereas the downfield shifted $\mathrm{Th}-{ }^{13} \mathrm{CH}_{3}$ signal at $\delta \sim 60 \mathrm{ppm}$ indicates formation of a "cation-like" electron-deficient organothorium species as in Scheme 1 Pathway A [97-99]. No evidence of $\mathrm{Cp}^{*}$ protonation or redox processes are observed. Interestingly, homogeneous solutions of $\mathrm{Cp}_{2}{ }^{*}$ $\mathrm{Th}\left(\mathrm{CH}_{3}\right)_{2}$ are minimally active for ethylene polymerization and olefin hydrogenation [100-104]. On the other hand, on adsorption DA results in a profound increase in catalytic activity [86, 105]. However, by means of quantitative poisoning experiments using either $\mathrm{H}_{2} \mathrm{O}$ or $\mathrm{CO}$ as probes, it was shown that only $\sim 4 \%$ of the $\mathrm{Cp}_{2} * \mathrm{Th}\left(\mathrm{CH}_{3}\right)_{2} / \mathrm{DA}$ sites are ethylene polymerization/olefin hydrogenation active [86, 96, 104, 106-110].

In order to test the generality of the supported organoactinide chemistry discussed above, group 4 zirconocenes have also been supported on dehydroxylated $\gamma$-alumina [111]. Analogous to the ${ }^{13} \mathrm{C}$ CPMAS NMR experiments performed with $\mathrm{Cp}^{*}{ }_{2} \mathrm{Th}\left({ }^{13} \mathrm{CH}_{3}\right)_{2}, \mathrm{Cp}_{2} \mathrm{Zr}\left({ }^{13} \mathrm{CH}_{3}\right)_{2}$ supported on DA produces cationic complexes via methide transfer to the surface, while the same precursor supported on PDA yields both $\mu$-oxo (Scheme 1 Pathway B) and cationic species, indicative of the presence of both weak Brønsted and Lewis acid sites. Measurements of evolved $\mathrm{CH}_{4}$ during the supporting reaction find similar yields for both thorium and zirconium species on DA, while lower yields were observed for zirconium species on PDA, likely due to the increased protonolytic stability of Zr-alkyl bonds [112]. 


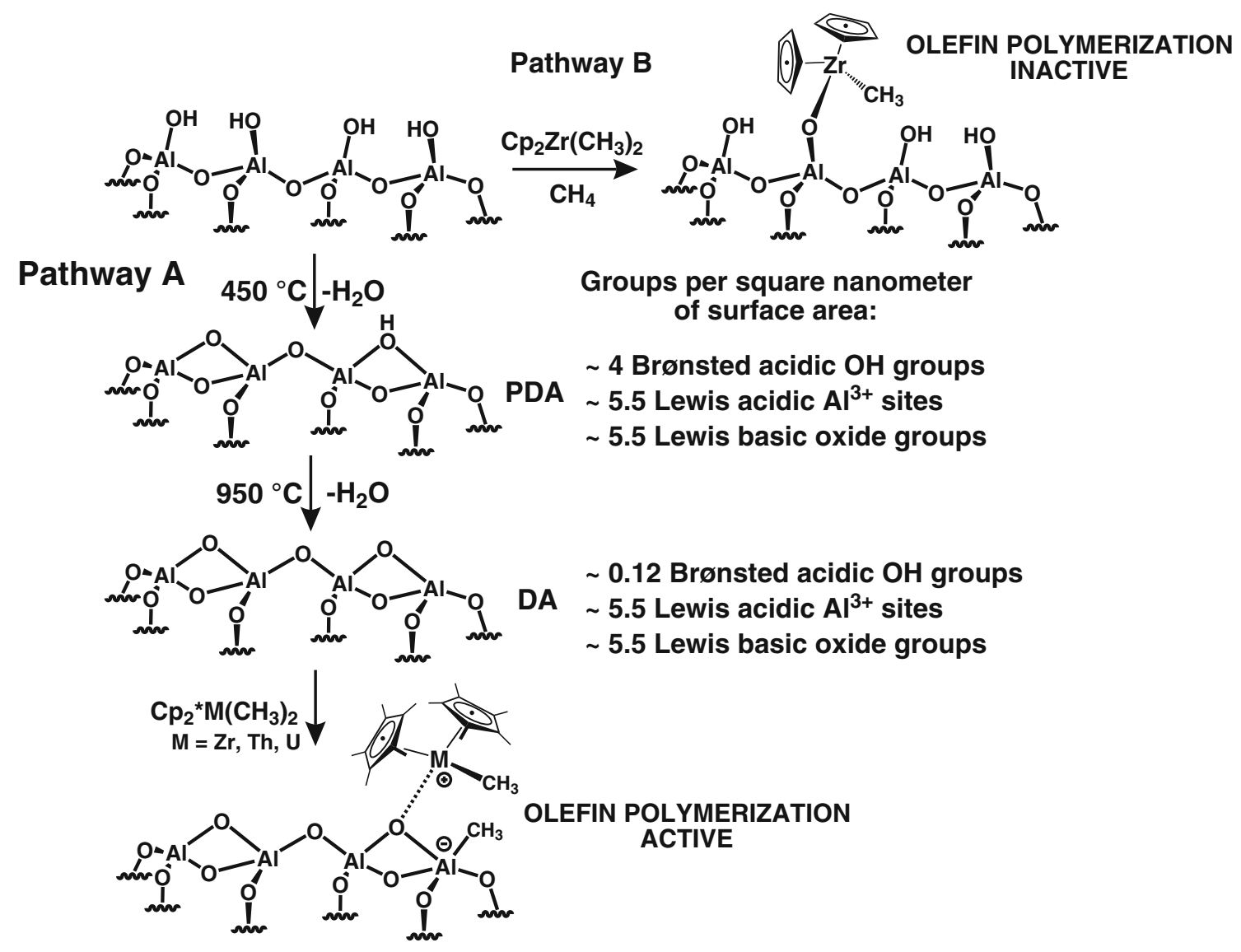

Scheme 1 Pathway A: synthesis of $D A$ dehydroxylated $\gamma$-alumina, $P D A$ partially dehydroxylated $\gamma$-alumina, and supported cationic organometallic catalyst. Pathway B: supported neutrally charged $\mu$-oxo organometallic complex on $\gamma$-alumina

The catalytic activity of the group 4 complexes was tested for propylene hydrogenation and ethylene polymerization. For those supported on DA, activity was generally found to be approximately $30 \%$ of that of related organoactinide catalysts. However, in marked contrast to organoactinides, organozirconium complexes on PDA also showed reactivity for propylene hydrogenation. Active site measurements for organozirconium complexes on DA indicated that for $\mathrm{Cp}_{2} \mathrm{Zr}\left(\mathrm{CH}_{3}\right)_{2} / \mathrm{DA}, \sim 4 \%$ of sites are active, and for $\mathrm{Cp} * \mathrm{Zr}\left(\mathrm{CH}_{3}\right)_{3} / \mathrm{DA}, \sim 12 \%$ are active, roughly mirroring the previous results for organoactinides on DA.

Periodic density functional calculations has been performed to investigate the structural and catalytic properties of the organozirconium precatalyst $\mathrm{Cp}_{2} \mathrm{Zr}\left(\mathrm{CH}_{3}\right)_{2}$, chemisorbed on a model dehydroxylated $\gamma$-alumina (110) surface [113]. Two different prototypical surface oxide environments, namely $\mu_{3}-\mathrm{O}$ and $\mu_{2}-\mathrm{O}$, can interact with the $\mathrm{Cp}_{2}$ $\mathrm{ZrCH}_{3}{ }^{+}$adsorbate (Fig. 7). The interaction of the $\mathrm{Cp}_{2}$ $\mathrm{ZrCH}_{3}{ }^{+}$adsorbate species with the $\mu_{2}-\mathrm{O}$ sites is far stronger than that with the $\mu_{3}-\mathrm{O}$ sites due to the greater coordinative unsaturation of the former. Moreover, the interaction with the $\mu_{3}-\mathrm{O}$ sites is weaker than that in the parent homogeneous $\mathrm{Cp}_{2} \mathrm{ZrCH}_{3}{ }^{+} \mathrm{H}_{3} \mathrm{CB}\left(\mathrm{C}_{6} \mathrm{~F}_{5}\right)_{3}^{-}$ion pair structure. The energetics of catalytic processes for the chemisorbed $\mathrm{Cp}_{2} \mathrm{ZrCH}_{3}{ }^{+}$sites for ethylene polymerization was examined at both $\mu_{2}-\mathrm{O}$ and $\mu_{3}-\mathrm{O}$ environments and compared to the analogous homogeneous catalyst. A Cossee enchainment mechanism proceeds via ethylene $\pi$-complex formation and an $\alpha$-agostic assisted transition state to yield $\gamma$ - and $\beta$-agostic insertion products. The overall kinetics of enchainment are closely correlated with the energetics of $\pi$-complex formation, and it is suggested that the differing kinetic behaviors of the surface-bound $\mathrm{Cp}_{2} \mathrm{ZrR}^{+}$species on the various $\mathrm{Al}_{2} \mathrm{O}_{3}$ coordination sites and the analogous homogeneous species reflect differences in the olefin $\pi$-complex stabilization energies. Specifically, the activation energy for olefin insertion rises in the order $\mu_{3}-\mathrm{O}$ site $<$ homogeneous $\mathrm{Cp}_{2} \mathrm{ZrCH}_{3}{ }^{+} \mathrm{H}_{3} \mathrm{CB}\left(\mathrm{C}_{6} \mathrm{~F}_{5}\right)_{3}^{-}$catalyst $<\mu_{2}-\mathrm{O}$ site.

\subsection{Sulfated Metal Oxides}

Sulfated metal oxides (SMOs) have received significant attention in the past as environmentally friendly 
Fig. 7 a Dioxo- and b oxo-bridged zirconocenium coordination on an alumina $\mu_{2}-\mathrm{O}$ site. c Dioxo- and d oxo-bridged zirconocenium coordination on a $\mu_{3}-\mathrm{O}$ alumina surface site. Adapted with permission from $\mathrm{J}$ Am Chem Soc (2008) 130:16533-16546 [113]. Copyright 2008 American Chemical Society
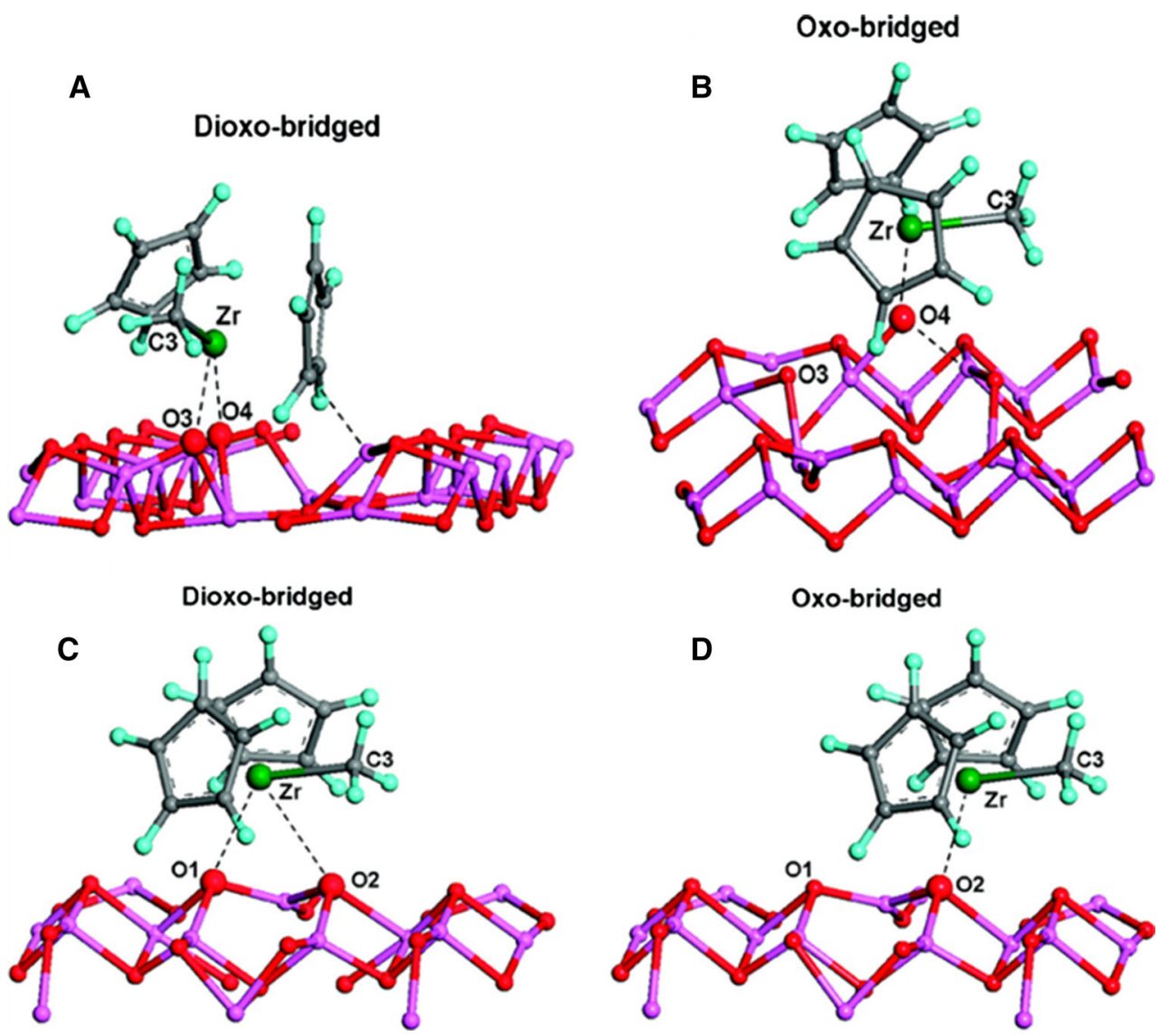

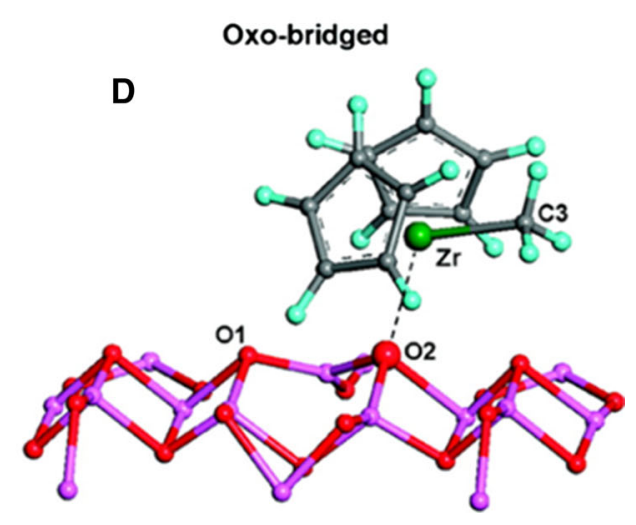

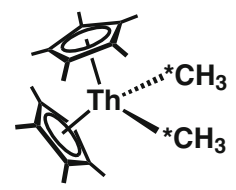

$1,1^{*}$<smiles>CC(C)(C1=CC1)C1CC1</smiles>

$4,4^{*}$<smiles></smiles>

$2,2^{*}$<smiles>CC(C)(C)C[Z17](CC(C)(C)C)(CC(C)(C)C)CC(C)(C)C</smiles>

5

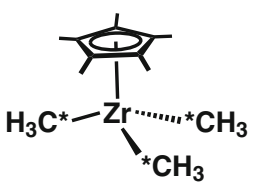

$3,3^{*}$

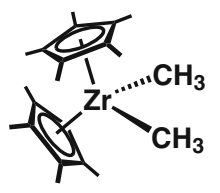

6
Fig. 8 Molecular precursors for chemisorption on SMOs to produce anchored catalysts

alternatives for superacid catalyzed reactions, such as the skeletal isomerization of alkanes [114] and the production of biodiesel [115]. To this end, a variety of oxides have been sulfated, such as zirconia ( $\mathrm{ZrS}, \mathrm{H}_{0}=-16$ ), alumina (AlS, $\mathrm{H}_{0}=-14.6$ ), stannia ( $\left.\mathrm{SnS}, \mathrm{H}_{0}=-18\right)$, hematite ( $\mathrm{FeS}$, $\mathrm{H}_{0}=-13$ ), and titania (TiS, $\mathrm{H}_{0}=-14.6$ ), [116] typically by exposure to a sulfation reagent, the most common of which is sulfuric acid, and subsequent calcination. As

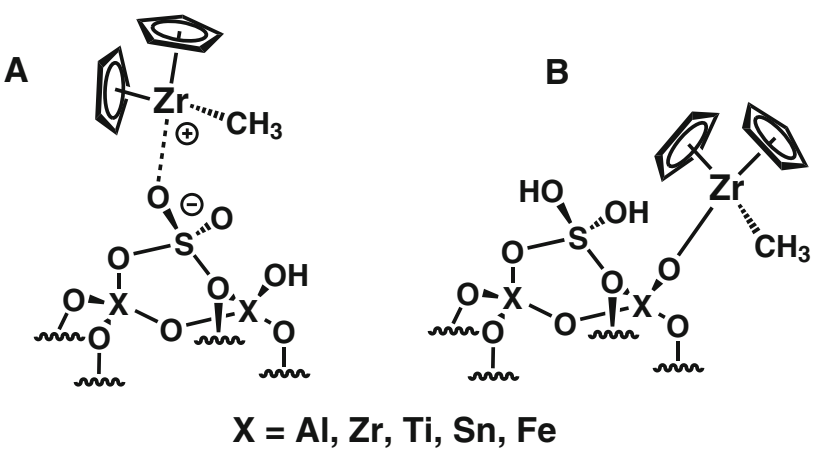

Fig. 9 Proposed structures of zirconocenium complex supported on sulfated metal oxides

supports for single site catalysts, sulfated metal oxides are particularly well-suited due to the presence of a generally large concentration of strong Brønsted and Lewis acid sites, which yield highly active 'cationic' metal adsorbate centers (vide supra). Similar to the studies discussed previously with PDA and DA, the use of model adsorbates (Fig. 8) along with ${ }^{13} \mathrm{C}$ CPMAS NMR techniques have been valuable in elucidating the surface character of these SMOsorganometallic complexes/catalysts (Fig. 9). 
Scheme 2 Synthesis of monometallic CGC-Zr catalysts supported on sulfated metal oxides
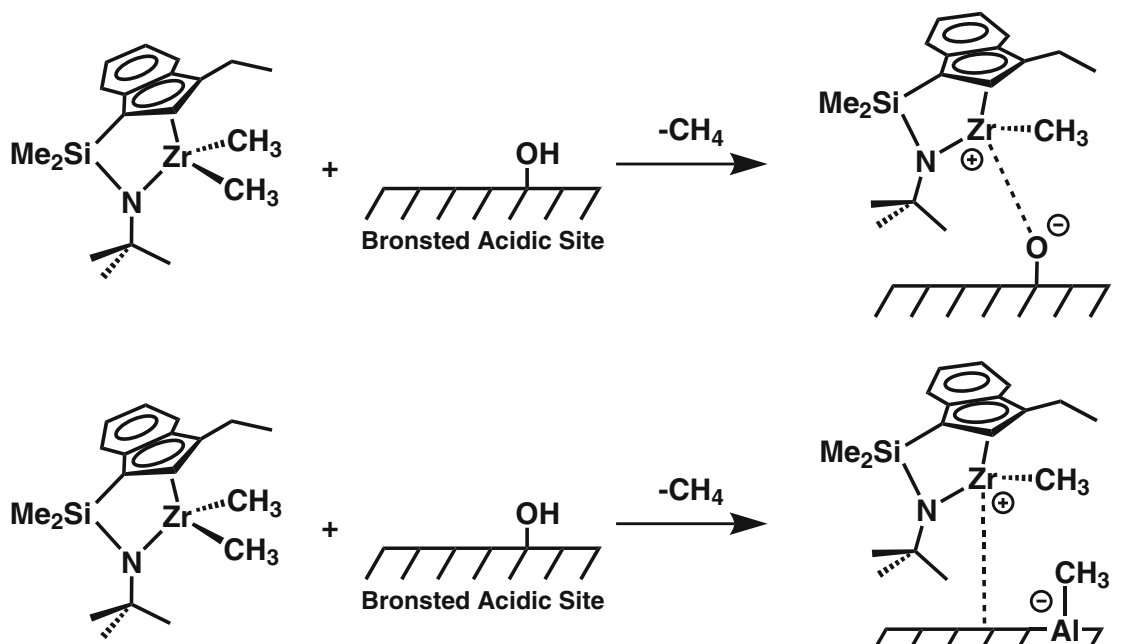

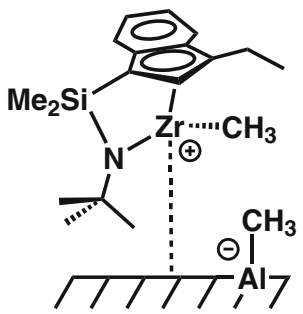

Sulfated zirconia $(\mathrm{ZrS})$ was one of the first SMOs investigated by our group [117-119]. Initial studies of the surface characteristics of $\mathrm{ZrS}$ were performed by the chemisorption of ${ }^{13} \mathrm{C}$ labeled $\mathrm{Cp}_{2}{ }_{2} \mathrm{Th}\left({ }^{13} \mathrm{CH}_{3}\right)_{3}\left(1^{*}\right)$ [118]. The ${ }^{13} \mathrm{C}$ CPMAS spectrum of $1 * / \mathrm{ZrS}$ compared to that of $1 * / \mathrm{DA}$ revealed important differences in the chemisorption pathways. Specifically, the peak resulting from methide transfer is substantially diminished, suggestive of only a small density of Lewis sites on the $\mathrm{ZrS}$ surface. The shift of the $\mathrm{Th}^{13}{ }^{13} \mathrm{CH}_{3}{ }^{+}$resonance to lower field also denotes a more electrophilic 'cationic' metal center (Scheme 1, Pathway A), resulting from the greater surface acidity and suggesting a more active catalytic site (vide infra). The minimal presence of hydrocarbyl transfer to the surface and increased electrophilicity of the adsorbate metal center are also confirmed with adsorbates $\mathrm{CpTi}\left({ }^{13} \mathrm{CH}_{3}\right)_{2} /$ $\mathrm{ZrS}(\mathbf{2} * / \mathbf{Z r S}), \mathrm{Cp} * \mathrm{Zr}\left({ }^{13} \mathrm{CH}_{3}\right)_{2} / \mathrm{ZrS}\left(\mathbf{3}^{*} / \mathbf{Z r S}\right), \mathrm{Cp}_{2} \mathrm{Zr}^{13} \mathrm{CH}_{3} /$ $\mathrm{ZrS}\left(\mathbf{4}^{*} / \mathrm{ZrS}\right)$, and $\mathrm{Zr}\left({ }^{\mathrm{t}} \mathrm{Bu}\right)_{3} / \mathrm{ZrS} . \mathbf{1}^{*} / \mathrm{ZrS}$ is also observed to have the most downfield shifted resonance for $\mathrm{Zr}^{13} \mathrm{CH}_{3}{ }^{+}$ when compared with homogeneous analogues, indicating the highly electrophilic character of the metal center (Scheme 2).

Other SMOs, including AlS [117, 120-123], SnS [117], FeS [117], and TiS [117] were analyzed in a similar way and found to yield analogous surface species. In comparing a given series, it is noted that the magnitude of the shift in resonances between the precursor and the adsorbate qualitatively correlates with the electronic unsaturation of the electrophilic species (Table 1). For $4^{*}$ chemisorbed on AlS, SnS, and TiS, mainly 'cationic' species (A), with small amounts of $\mu$-oxo (B) present in $\mathrm{SnS}$, are produced via protonolytic chemisorption of $4^{*}$, with methide transfer remaining below the detection limits, implying the presence of primarily strong Brønsted sites. For $4 * / \mathrm{ZrS}$, however, $\mu$-oxo species are formed, with protonolysis by weak Brønsted acid sites dominating, and a small,
Table $1{ }^{13} \mathrm{C}$ CPMAS NMR parameters for model adsorbates on various SMOs

\begin{tabular}{lll}
\hline Complex & $\mathrm{M}-\mathrm{CH}_{3}(\delta)$ & $\mathrm{Cp}(\delta)$ \\
\hline $\mathrm{Cp}_{2} \mathrm{Zr}\left({ }^{13} \mathrm{CH}_{3}\right)_{2}$ & 30.45 & 110.45 \\
$\mathrm{Cp}_{2} \mathrm{Zr}^{13} \mathrm{CH}_{3} / \mathrm{ZrS}$ & 37.1 & 114.1 \\
$\mathrm{Cp}_{2} \mathrm{Zr}^{13} \mathrm{CH}_{3} / \mathrm{SnS}$ & 35.7 and 20.5 & 113.8 \\
$\mathrm{Cp}_{2} \mathrm{Zr}^{13} \mathrm{CH}_{3} / \mathrm{FeS}$ & 37.6 and 21.7 & 110.7 \\
$\mathrm{Cp}_{2} \mathrm{Zr}^{13} \mathrm{CH}_{3} / \mathrm{TiS}$ & 33.8 & 113.4 \\
$\mathrm{Cp}^{*}{ }_{2} \mathrm{Zr}^{13} \mathrm{CH}_{3}$ & 36.8 & 117.4 \\
$\mathrm{Cp}^{*}{ }_{2} \mathrm{Zr}^{13} \mathrm{CH}_{3} / \mathrm{AlS}$ & 46.0 & 123.0 \\
$\mathrm{Cp}^{*}{ }_{2} \mathrm{Zr}^{13} \mathrm{CH}_{3} / \mathrm{n}$-AlS & 43.0 & 123.3 \\
\hline
\end{tabular}

downfield shifted resonance for 'cationic' species also observed. Nanoparticles of AlS (n-AlS) [121] yield similar structural results to bulk AlS, except for a larger presence of methide transfer, indicative of a higher density of Lewis acid sites. $\mathrm{n}$-AlS also enables increased loadings of $\mathrm{Zr}$ due to minimized internal surface area.

Adsorption of organo-group 4 complexes on AlS was also studied by extended X-ray absorption fine structure (EXAFS) and periodic density function theory (DFT) computation in order to gain a more realistic understanding of the structural characteristics of the adsorbates on SMOs. [120]. Zr K-edge EXAFS data were collected under strictly anhydrous/anaerobic conditions and, due to the structural complexity of the supported moieties, difference spectra (before and after chemisorption) were utilized, since changes in the metal ligation are of primary interest. For $4 * / \mathrm{AlS}$, the $\mathrm{Zr}-\mathrm{O}_{\text {support }}$ bond length is found to be $2.37 \pm 0.02 \AA$, which is significantly elongated from typical literature covalent $\mathrm{Zr}(\mathrm{IV})-\mathrm{OR}$ bond lengths, $2.000 \pm 0.002 \AA[120]$, supporting the ${ }^{13} \mathrm{C}$ CPMAS NMR characterization of loose ion pairing between the 'cationic' metal adsorbate and the negative charged-delocalized 

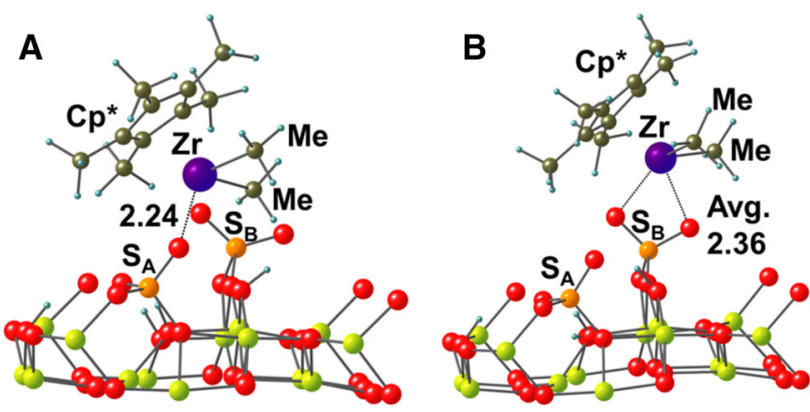

Fig. 10 Energy-minimized computed chemisorbed catalyst structures for: a $\mathrm{Cp} * \mathrm{Zr}\left(\mathrm{CH}_{3}\right)_{2}^{+}$coordination to the $\mathrm{S}=\mathrm{O}$ groups of the sulfated alumina surface at $\mathrm{S}_{\mathrm{A}}$ sites. b $\mathrm{Cp} * \mathrm{Zr}\left(\mathrm{CH}_{3}\right)_{2}^{+}$coordination to the $\mathrm{S}=\mathrm{O}$ groups of the sulfated alumina surface at $S_{B}$ sites. Distances in $\AA$. Avg. $=$ average distance. $\mathrm{Zr}=$ purple, $\mathrm{C}=$ olive, $\mathrm{H}=$ blue, $\mathrm{O}=$ red, $\mathrm{S}=$ orange, $\mathrm{Al}=$ yellow-green. Adapted with permission from Proc Nat Acad Sci USA (2013) 110:413-418 [120]

surface. This is further supported by DFT calculations, which, based on two potential types of sulfate site (Fig. 10), find mean $\mathrm{Zr}-\mathrm{O}_{\text {support }}$ distances of 2.22 and $2.42 \AA$. As for the interaction between the adsorbate and the surface, the EXAFS difference spectra reveal a $\mathrm{CN}=2.1$, such that the negative charge on the surface is delocalized between two proximate oxygen atoms that both bind to the metal center. After exposure to benzene under hydrogenation conditions, DFT calculations predict insertion of the benzene between the $\mathrm{Zr}^{+} \ldots \overline{\mathrm{O}}$ bond, which finds close analogy to the ion pair weakening and anion displacement in activated homogeneous early transition metal polymerization catalysts upon olefin approach/activation.

In the interest of expanding the variety of supported organometallic moieties, constrained geometry catalysts (CGC, Fig. 11) [124] were also chemisorbed onto AlS [122]. CGCs are valued for their increased thermal stability and favorable incorporation of comonomers during polymerization, resulting in long chain branching polymers, due to more open coordination spheres. The formation of cationic surface species was further verified by a distinct color change, from colorless to yellow (for organozirconium complexes) or colorless to orange (for organotitanium complexes), which is analogous to the color change observed during homogenous activation with organo-Lewis acids such as $\mathrm{B}\left(\mathrm{C}_{6} \mathrm{~F}_{5}\right)_{3}$. For the bimetallic 9/AlS, both the number of metal centers activated (one or both) and the type (protonolytic or methide transfer) of chemisorption permits the exact structural characterization of this adsorbate (Fig. 12). The integration of the 9/AlS ${ }^{13} \mathrm{C}$ CPMAS NMR resonances suggests that the majority of adsorbate species have both metal centers activated, while the integration of the $\mathrm{Zr}-{ }^{13} \mathrm{Me}: \mathrm{Al}-\mathrm{Me}$ resonances in the ${ }^{13} \mathrm{C}$ CPMAS NMR is found to be 1:0.6, whereas a ratio of $\sim 3: 1$ is expected for activation of a single metal center. Thus, both metals in the bimetallic precursor are likely activated, approximately $40 \%$ by metal-hydrocarbyl protonolytic chemisorption and $60 \%$ by methide transfer to the surface.

Following structural and chemical characterization of the chemisorption pathways, olefin homo- and copolymerizations underscore the catalytic utility of SMOs as activators and weakly coordinating anions. For the catalysts discussed here, the principal product of ethylene polymerization is HDPE with minimal branching and ultrahigh molecular weight, as observed in previous studies of organozirconium hydrocarbyls supported on alumina (vide supra). For ethylene homopolymerizations using $\mathrm{ZrS}$ and AlS as supports (118-120; 124), a number of adsorbates with varying electronic and coordinative saturation were assayed (Table 2). In general, polymerization activity is found to increase with increasing coordinative unsaturation, such that $\mathrm{Zr}\left(\mathrm{CH}_{2} \mathrm{Ph}\right)_{4}>\mathrm{Cp} * \mathrm{Zr}\left(\mathrm{CH}_{3}\right)_{3}$ for every SMO. As for support effects, activity follows the trend $\mathrm{ZrS} \geq \mathrm{AlS}>\mathrm{SnS}>\mathrm{FeS}>\mathrm{TiS}$. Importantly, AlS is found to have an ethylene homopolymerization activity almost10x that of $\mathrm{Cp}^{*} \mathrm{Zr}\left(\mathrm{CH}_{3}\right)_{3} / \mathrm{DA}\left(1.2 \times 10^{5} \mathrm{~g} \mathrm{PE} / \mathrm{mol}\right.$ $\mathrm{Zr} \mathrm{h}$ ), proving that chemisorption on SMOs yields more active 'cationic' centers, reflecting both the increased number of active sites and their 'cationic' nature (vide infra). Nanoparticle-AIS is also found to be an effective activator and high surface area support for the rapid production of high molecular weight PE and its performance is found to be solvent dependent, heptane $>$ toluene, likely due to the coordinative inhibition of arenes at the electrophilic active sites [126]. Although solvent dependence was only tested on n-AlS supported catalysts, all SMO adsorbates are expected to exhibit similar behavior due to their mainly 'cationic' character.

One of the principal attractions of SMOs is the high percentage of zirconium adsorbate sites that are catalytically significant. In situ kinetic poisoning experiments performed on the above catalysts reveal the high number of active sites, with $>60 \%$ for all SMOs except FeS attainable, compared to $\sim 12 \%$ for $\mathrm{Cp} * \mathrm{Zr}\left(\mathrm{CH}_{3}\right)_{3} / \mathrm{DA}$ and $<6 \%$ for $\mathrm{Zr}\left(\mathrm{CH}_{2} \mathrm{CMe}_{2} \mathrm{Ph}\right)_{4} / \mathrm{PDA}$ [112]. While there is no direct correlation between acidity and percentage active sites, for the SMOs discussed here, it appears that materials with $\mathrm{H}_{0}<-14$ have a high percentage of active sites. It has been concluded that the exceptional catalytic activity of these zirconium hydrocarbyl adsorbate catalysts reflects an interplay of both the high percentage of active sites and the electrophilicity of such sites, such that both are required for an active catalyst. For example, TiS as a support has $63 \pm 9 \%$ active sites, but ${ }^{13} \mathrm{C}$ CPMAS NMR reveals that most of these are of the active $\mu$-oxo type (vide supra), thus the catalyst performs relatively poorly. The attraction of using SMOs as supports/activators thus lies in the fact that 
Fig. 11 Mononuclear and binuclear CGC-zirconium catalysts

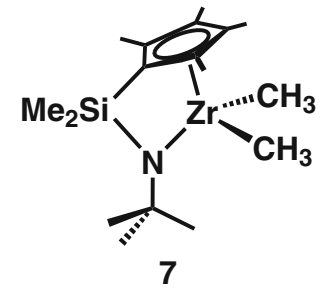

7

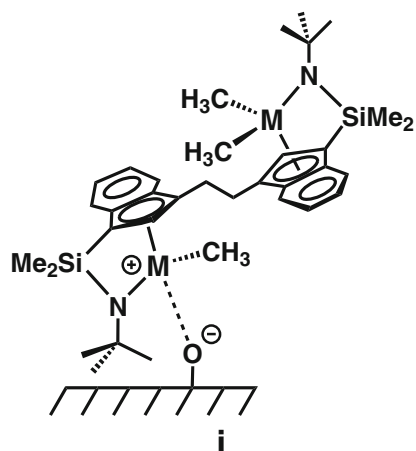

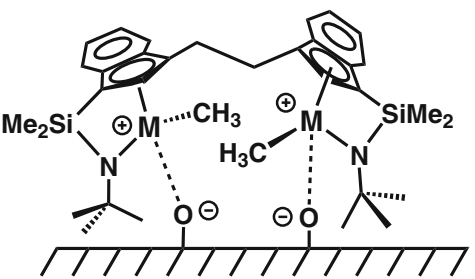

iii

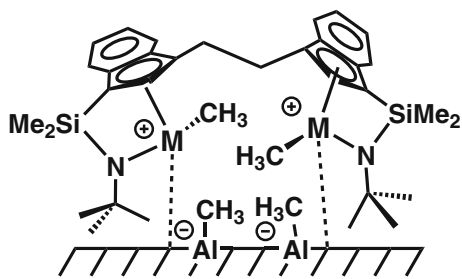

iv

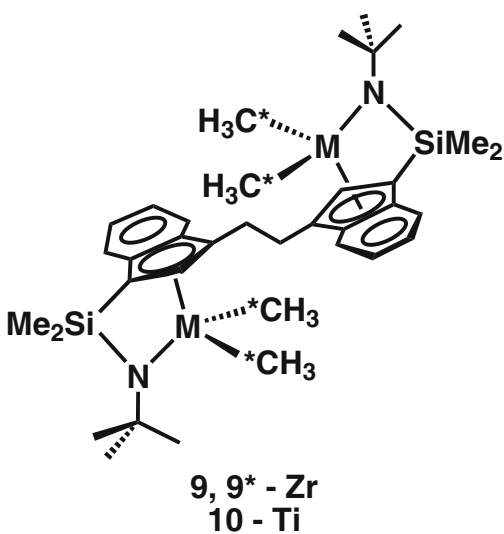

ii

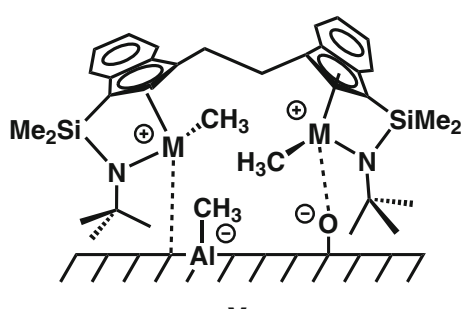

v

strong Brønsted centers; (iv) Both metal centers chemisorbed via methide transfer on proximate Lewis acid sites; (v) One metal center protonolytically chemisorbed, the other chemisorbed by methide transfer by the type and concentration of acid sites: (i) Single metal center protonolytically chemisorbed on a strong Brønsted acid site; (ii) Single metal center chemisorbed via methide transfer on a Lewis acid site; (iii) Both metal centers protonolytically chemisorbed on proximate

they provide both highly active electrophilic single catalytic sites, and due to their high acidity, nearly $100 \%$ of these sites are catalytically active.

The CGC catalysts supported on AlS were also evaluated for ethylene homopolymerization, along with ethylene/1hexene copolymerization [122]. Ethylene homopolymerizations are found to yield high molecular weight PE as determined by DSC, and to be highly crystalline with low branch densities, but in all cases, the corresponding supported catalysts have lower catalytic activity than the homogenous analogs, which is attributed to steric repulsion of the support and the adsorbate ligands. Analogously to homogeneous systems [127], the bimetallic $\mathrm{Ti}_{2} / \mathrm{AlS}$ is more active than bimetallic $\mathrm{Zr}_{2} / \mathrm{AlS}$. Concerning ethylene/1-hexene copolymerizations, the supported catalysts are again less active than their homogenous equivalents. Minimal comonomer enchainment is observed $\left(\mathrm{T}_{\mathrm{m}}\right.$ depressed only $3-5^{\circ} \mathrm{C}$ from the homopolymer) and it is likely that the steric bulk of the bimetallic $\mathrm{Zr}_{2}$ and $\mathrm{Ti}_{2}$ limits 1-hexene approach, thereby frustrating the bimetallic cooperativity observed in homogenous systems.

\section{Conclusion and Prospectus}

This Review analyzes the effects on olefin polymerization by single-site catalysts supporting them on various oxides and sulfated oxides. The well-established synthetic routes to achieve single-site heterogeneous catalysts and the diverse 
Table 2 Ethylene homopolymerization data for SMO supported zirconium hydrocarbyls

\begin{tabular}{|c|c|c|c|c|c|c|}
\hline Entry & Support & Zr hydrocarbyl & Activity $^{c} \times 10^{5}$ & $\mathrm{~T}_{\mathrm{m}}\left({ }^{\circ} \mathrm{C}\right)$ & $\begin{array}{l}\text { Active sites } \\
\%\end{array}$ & $\begin{array}{l}\text { Acidity } \\
\mathrm{H}_{0}\end{array}$ \\
\hline 1 & $\mathrm{ZrS}$ & $\mathrm{Cp} * \mathrm{Zr}\left(\mathrm{CH}_{3}\right)_{3}$ & 7.7 & 133.1 & $\sim 65^{\mathrm{f}}$ & -16 \\
\hline 2 & $\mathrm{ZrS}$ & $\mathrm{Zr}\left(\mathrm{CH}_{2} \mathrm{Ph}\right)_{4}$ & 25 & 134.0 & & \\
\hline 3 & AlS & $\mathrm{Cp} * \mathrm{Zr}\left(\mathrm{CH}_{3}\right)_{3}$ & 11 & 133.6 & $87 \pm 3$ & -14.6 \\
\hline 4 & AlS & $\mathrm{Zr}\left(\mathrm{CH}_{2} \mathrm{Ph}\right)_{4}$ & 21 & 134.2 & & \\
\hline 5 & $\mathrm{SnS}$ & $\mathrm{Cp} * \mathrm{Zr}\left(\mathrm{CH}_{3}\right)_{3}$ & 0.98 & 136.1 & $61 \pm 5$ & -18 \\
\hline 6 & $\mathrm{SnS}$ & $\mathrm{Zr}\left(\mathrm{CH}_{2} \mathrm{Ph}\right)_{4}$ & 6.6 & 135.1 & & \\
\hline 7 & $\mathrm{FeS}$ & $\mathrm{Cp} * \mathrm{Zr}\left(\mathrm{CH}_{3}\right)_{3}$ & 0.24 & 134.2 & $22 \pm 2$ & $-13^{\mathrm{g}}$ \\
\hline 8 & $\mathrm{FeS}$ & $\mathrm{Zr}\left(\mathrm{CH}_{2} \mathrm{Ph}\right)_{4}$ & 5.1 & 135.2 & & \\
\hline 9 & TiS & $\mathrm{Cp} * \mathrm{Zr}\left(\mathrm{CH}_{3}\right)_{3}$ & 0.012 & 138.4 & $63 \pm 9$ & -14.6 \\
\hline 10 & TiS & $\mathrm{Zr}\left(\mathrm{CH}_{2} \mathrm{Ph}\right)_{4}$ & 0.63 & 138.0 & & \\
\hline
\end{tabular}

${ }^{\text {a }}$ Carried out at $60{ }^{\circ} \mathrm{C}, 150 \mathrm{psi}$ of ethylene, $5.0 \mathrm{~mL}$ toluene

${ }^{\text {b }} \mathrm{Cp}^{*}=\eta^{5}-\mathrm{C}_{5} \mathrm{Me}_{5}$

${ }^{\mathrm{c}}$ Units: grams of total polymer/(mol $\left.\mathrm{Zr} \mathrm{h}\right)$

${ }^{\mathrm{d}}$ Number of active sites determined by poisoning ethylene polymerization of $\mathrm{Cp} * \mathrm{Zr}\left(\mathrm{CH}_{3}\right)_{3} / \mathrm{SMO}$ with neopentyl alcohol

e From Ref [89], measured by the spectrophotometric indicator method, except for SnS from Ref. [125]

${ }^{\mathrm{f}}$ From Ref [118] Number of active sites determined by poisoning benzene hydrogenation of $\mathrm{Cp} * \mathrm{Zr}\left(\mathrm{CH}_{3}\right)_{3} / \mathrm{ZrS}$ with $\mathrm{H}_{2} \mathrm{O}$

g Estimated from TDP and activity for butane isomerization due to competing optical properties of the support

techniques (SS NMR, EXAFS, DFT calculations) for their characterization are described. Solid state NMR and EXAFS studies show that alkyl migration from the organometallic precursor to the Lewis acidic sites constitutes the principal adsorption pathway on dehydroxylated alumina (DA), whereas the chemisorption of the same organometallic molecules on highly Brønsted "super-acidic" sulfated metal oxides yields, via $\mathrm{Zr}-\mathrm{CH}_{3}$ protonolysis with methane evolution, highly electrophilic adsorbate species. The resulting "cation-like" species, reminiscent of the homogeneous analogues, are highly active heterogeneous catalysts for olefin polymerization and hydrogenation, with generally high percentages of catalytically significant sites. In many cases, extraordinarily high percentages $(\sim 100 \%)$ of catalytically significant sites can be attained, permitting accurate structure determination and isolation/characterization of reaction intermediates.

Acknowledgments Financial support by DOE Basic Energy Sciences (Grant 86ER13511) is gratefully acknowledged.

\section{References}

1. ACS Division of Polymer Chemistry: Advances in Polyolefins 2013, Santa Rosa

2. Tabone MD, Cregg JJ, Beckman EJ, Landis AE (2010) Environ Sci Technol 44:8264-8269

3. James DE (1985) In: Mark HF, Bikales NM, Overberger CG, Menges $G$ (eds) Linear low density polyethylene in encyclopedia of polymer science and engineering, vol 6. Wiley-Interscience, New York, pp 429-454
4. Munstedt H (2011) Soft Matter 7:2273-2283

5. Theopold KH (2014) Proc Natl Acad Sci USA 111:11578-11579

6. McDaniel MP (2010) Adv Catal 53:123-606

7. Zecchina A, Groppo E, Damin A, Prestipino C (2005) Top Organomet Chem 16:1-35

8. http://nobelprize.org/nobel_prizes/chemistry/laureates/1963/

9. Abedi S, Abdouss M (2014) Appl Catal A 475:386-409

10. Claverie JP, Schaper F (2013) MRS Bull 38:213-218

11. Eisch JJ (2012) Organometallics 31:4917-4932

12. Corradini P, Guerra G, Cavallo L (2004) Acc Chem Res 37:231-241

13. Kaminsky W (2012) Macromolecules 45:3289-3297

14. Kaminsky W, Funck A, Haehnsen H (2009) Dalton Trans 41:8803-8810

15. Kaminsky W (2004) J Polym Sci A 42:3911-3921

16. Wang B (2006) Coord Chem Rev 250:242-258

17. Razavi A, Thewalt U (2006) Coord Chem Rev 250:155-169

18. Mohring PC, Coville NJ (2006) Coord Chem Rev 250:18-35

19. Wang W, Wang L (2003) J Polym Mater 20:1-8

20. Kulshreshtha AK, Awasthi SK (2000) Pop Plast Packag 45:53-57

21. Kristen MO (1999) Top Catal 7:89-95

22. Chien JCW (1999) Top Catal 7:23-36

23. Ban HT, Arai T, Ahn C-H, Uozuml T, Soga K (1999) Curr Trends Polym Sci 4:47-64

24. Ciardelli F, Altomare A, Michelotti M (1998) Catal Today 41:149-157

25. Yang X, Stern CL, Marks TJ (1994) J Am Chem Soc 116:10015-10031

26. Yang X, Stern CL, Marks TJ (1991) J Am Chem Soc 113:3623-3625

27. Ewen JA, Elder MJ (1996) Eur Patent Appl 0,427,697, 1991; US Patent 5,561,092, 1996

28. Bochmann M (2010) Acc Chem Res 43:1267-1278

29. Bochmann M (2010) Organometallics 29:4711-4740

30. Chen EYX, Marks TJ (2000) Chem Rev 100:1391-1434

31. Chum PS, Swogger KW (2008) Progress Poly Sci 33:797-819 
32. Delferro M, Marks TJ (2011) Chem Rev 111:2450-2485

33. Budagumpi S, Kim K-H, Kim I (2011) Coord. Chem Rev 255:2785-2809

34. Gibson VC, Spitzmesser SK (2003) Chem Rev 103:283-315

35. Trifonov AA (2007) Russ Chem Rev 76:1051-1072

36. Fujita T, Kawai K (2014) Top Catal 57:852-877

37. Iwashita A, Chan MCW, Makio H, Fujita T (2014) Catal Sci Technol 4:599-610

38. Kawai K, Fujita T (2009) Top Organomet Chem 26:3-46

39. Makio H, Fujita T (2009) Acc Chem Res 42:1532-1544

40. Makio H, Terao H, Iwashita A, Fujita T (2011) Chem Rev 111:2363-2449

41. Matsugi T, Fujita T (2008) Chem Soc Rev 37:1264-1277

42. Mitani M, Saito J, Ishii S-I, Nakayama Y, Makio H et al (2004) Chem Rec 4:137-158

43. Connor EF, Younkin TR, Henderson JI, Waltman AW, Grubbs RH (2003) Chem Commun 18:2272-2273

44. Connor EF, Younkin TR, Henderson JI, Hwang S, Grubbs RH et al (2002) J Polym Sci A 40:2842-2854

45. Younkin TR, Connor EF, Henderson JI, Friedrich SK, Grubbs RH, Bansleben DA (2000) Science 287:460-462

46. Wang C, Friedrich S, Younkin TR, Li RT, Grubbs RH et al (1998) Organometallics 17:3149-3151

47. Tempel DJ, Johnson LK, Huff RL, White PS, Brookhart M (2000) J Am Chem Soc 122:6686-6700

48. Ittel SD, Johnson LK, Brookhart M (2000) Chem Rev 100:1169-1203

49. Svejda SA, Johnson LK, Brookhart M (1999) J Am Chem Soc 121:10634-10635

50. Mecking S, Johnson LK, Wang L, Brookhart M (1998) J Am Chem Soc 120:888-899

51. Rix FC, Brookhart M, White PS (1996) J Am Chem Soc 118:4746-4764

52. Johnson LK, Mecking S, Brookhart M (1996) J Am Chem Soc 118:267-268

53. Johnson LK, Killian CM, Brookhart M (1995) J Am Chem Soc 117:6414-6415

54. Drent E, van Dijk R, van Ginkel R, van Oort B, Pugh RI (2002) Chem Commun 1:744-745

55. Nakamura A, Anselment TMJ, Claverie J, Goodall B, Jordan RF et al (2013) Acc Chem Res 46:1438-1449

56. Wang X, Wang Y, Shi X, Liu J, Chen C, Li Y (2014) Macromolecules 47:552-559

57. Miyake GM, Chen EYX (2011) Polym Chem 2:2462-2480

58. Ito S, Nozaki K (2010) Chem Rec 10:315-325

59. Goodall BL (2009) Top Organomet Chem 26:159-178

60. Popeney CS, Camacho DH, Guan Z (2007) J Am Chem Soc 129:10062-10063

61. Soula R, Saillard B, Spitz R, Claverie J, Llaurro MF, Monnet C (2002) Macromolecules 35:1513-1523

62. Meneghetti SP, Kress J, Lutz PJ (2000) Macromol Chem Phy 201:1823-1832

63. Valente A, Stoclet G, Bonnet F, Mortreux A, Visseaux M, Zinck P (2014) Angew Chem Int Ed 53:4638-4641

64. Mohammadi Y, Ahmadi M, Saeb MR, Khorasani MM, Yang P, Stadler FJ (2014) Macromolecules 47:4778-4789

65. Wenzel TT, Arriola DJ, Carnahan EM, Hustad PD, Kuhlman RL (2009) Top Organomet Chem 26:65-104

66. Kuhlman RL, Wenzel TT (2008) Macromolecules 41:4090-4094

67. Arriola DJ, Carnahan EM, Hustad PD, Kuhlman RL, Wenzel TT (2006) Science 312:714-719

68. Wegener SL, Marks TJ, Stair PC (2012) Acc Chem Res 45:206-214

69. Basset J-M, Coperet C, Soulivong D, Taoufik M, Thivolle Cazat J (2010) J Acc Chem Res 43:323-334
70. Thomas A, Driess M (2009) Angew Chem Int Ed 48:1890-1892

71. Basset J-M, Coperet C, Soulivong D, Taoufik M, Thivolle-Cazat J (2006) Angew Chem Int Ed 45:6082-6085

72. Coperet C, Chabanas M, Saint-Arroman RP, Basset J-M (2003) Angew Chem Int Ed 42:156-181

73. Marks TJ (1992) Acc Chem Res 25:57-65

74. Joubert J, Delbecq F, Thieuleux C, Taoufik M, Blanc F et al (2007) Organometallics 26:3329-3335

75. Conley MP, Mougel V, Peryshkov DV, Forrest WP, Gajan D et al (2013) J Am Chem Soc 135:19068-19070

76. Merle N, Girard G, Popoff N, De Mallmann A, Bouhoute Y et al (2013) Inorg Chem 52:10119-10130

77. Popoff N, Mazoyer E, Pelletier J, Gauvin RM, Taoufik M (2013) Chem Soc Rev 42:9035-9054

78. Rhers B, Salameh A, Baudouin A, Quadrelli EA, Taoufik M et al (2006) Organometallics 25:3554-3557

79. Blanc F, Thivolle-Cazat J, Basset J-M, Coperet C, Hock AS et al (2007) J Am Chem Soc 129:1044-1045

80. Blanc F, Basset J-M, Coperet C, Sinha A, Tonzetich ZJ et al (2008) J Am Chem Soc 130:5886-5900

81. Blanc F, Berthoud R, Coperet C, Lesage A, Emsley L et al (2008) Proc Natl Acad Sci USA 105:12123-12127

82. Blanc F, Rendon N, Berthoud R, Basset JM, Coperet C, et al (2008) Dalton Trans 3156-3158. doi:10.1039/b805686m

83. Buchmeiser MR (2009) Chem Rev 109:303-321

84. Deraedt C, d'Halluin M, Astruc D (2013) Eur J Inorg Chem 2013:4881-4908

85. Thieuleux C, Coperet C, Dufaud V, Marangelli C, Kuntz E, Basset JM (2004) J Mol Catal A 213:47-57

86. Eisen MS, Marks TJ (1994) J Mol Catal 86:23-50

87. Rascon F, Wischert R, Coperet C (2011) Chem Sci 2:1449-1456

88. Arata K (2009) Green Chem 11:1719-1728

89. Arata K (1996) Appl Catal A 146:3-32

90. Arata K (1991) Trends Phys Chem 2:1-24

91. Delgado M, Delbecq F, Santini CC, Lefebvre F, Norsic S et al (2012) J Phys Chem C 116:834-843

92. Wischert R, Florian P, Coperet C, Massiot D, Sautet P (2014) J Phys Chem C 118:15292-15299

93. Wischert R, Laurent P, Coperet C, Delbecq F, Sautet P (2012) J Am Chem Soc 134:14430-14449

94. Popoff N, Gauvin RM, De Mallmann A, Taoufik M (2012) Organometallics 31:4763-4768

95. Millot N, Soignier S, Santini CC, Baudouin A, Basset JM (2006) J Am Chem Soc 128:9361-9370

96. Toscano PJ, Marks TJ (1985) J Am Chem Soc 107:653-659

97. Chen Y-X, Stern CL, Yang S, Marks TJ (1996) J Am Chem Soc 118:12451-12452

98. Yang X, Stern C, Marks TJ (1991) Organometallics 10:840-842

99. Lin Z, Le Marechal JF, Sabat M, Marks TJ (1987) J Am Chem Soc 109:4127-4129

100. Fendrick CM, Schertz LD, Day VW, Marks TJ (1988) Organometallics 7:1828-1838

101. Fagan PJ, Manriquez JM, Vollmer SH, Day CS, Day VW, Marks TJ (1981) J Am Chem Soc 103:2206-2220

102. Fagan PJ, Moloy KG, Marks TJ (1981) J Am Chem Soc 103:6959-6962

103. Fagan PJ, Manriquez JM, Maatta EA, Seyam AM, Marks TJ (1981) J Am Chem Soc 103:6650-6667

104. Bowman RG, Nakamura R, Fagan PJ, Burwell RL Jr, Marks TJ (1981) J Chem Soc Chem Commun 6:257-258

105. Eisen MS, Marks TJ (1992) J Am Chem Soc 114:10358-10368

106. Eisen MS, Marks TJ (1992) Organometallics 11:3939-3941

107. Gillespie RD, Burwell RL Jr, Marks TJ (1991) Catal Lett 9:363-368

108. Finch WC, Gillespie RD, Hedden D, Marks TJ (1990) J Am Chem Soc 112:6221-6232 
109. Toscano PJ, Marks TJ (1986) Langmuir 2:820-823

110. He MY, Xiong G, Toscano PJ, Burwell RL Jr, Marks TJ (1985) J Am Chem Soc 107:641-652

111. Dahmen KH, Hedden D, Burwell RL, Marks TJ (1988) Langmuir 4:1212-1214

112. Schock LE, Marks TJ (1988) J Am Chem Soc 110:7701-7715

113. Motta A, Fragala IL, Marks TJ (2008) J Am Chem Soc 130:16533-16546

114. Hino M, Kobayashi S, Arata K (1979) J Am Chem Soc 101:6439-6441

115. Su F, Guo Y (2014) Green Chem 16:2934-2957

116. Corma A (1995) Chem Rev 95:559-614

117. Nicholas CP, Marks TJ (2004) Langmuir 20:9456-9462

118. Ahn H, Nicholas CP, Marks TJ (2002) Organometallics 21: $1788-1806$

119. Ahn H, Marks TJ (1998) J Am Chem Soc 120:13533-13534
120. Williams LA, Guo N, Motta A, Delferro M, Fragala IL et al (2013) Proc Natl Acad Sci USA 110:413-418

121. Williams LA, Marks TJ (2011) ACS Catal 1:238-245

122. Williams LA, Marks TJ (2009) Organometallics 28:2053-2061

123. Nicholas CP, Ahn H, Marks TJ (2003) J Am Chem Soc 125:4325-4331

124. Braunschweig H, Breitling FM (2006) Coord Chem Rev 250:2691-2720

125. Matsuhashi H, Miyazaki H, Kawamura Y, Nakamura H, Arata K (2001) Chem Mater 13:3038-3042

126. Stalzer MM, Gu W, Nicholas CP, Bhattacharyya A, Motta A, Gallagher JR, Zhang G, Miller JT, Delferro M, Marks TJ (unpublished results)

127. McInnis JP, Delferro M, Marks TJ (2014) Acc Chem Res 47:2545-2557 